\title{
COMPARATIVE MORPHOLOGICAL AND ANATOMICAL STUDIES ON Iris peshmeniana Güner \& T. Hall. AND Iris aucheri (Baker) Sealy (IRIDACEAE)
}

\author{
Nezahat KANDEMİR \\ Amasya University, Faculty of Education, Department of Mathematics and Science Education, Amasya, TURKEY \\ ORCID ID: orcid.org/0000-0002-5428-4139, e-mail: nezahatkndmr@gmail.com
}

Cite this article as:

Kandemir N. 2019. Comparative Morphological and Anatomical Studies on Iris peshmeniana Güner \& T. Hall. and Iris aucheri (Baker) Sealy (Iridaceae). Trakya Univ J Nat Sci, 20(2): 105-113, DOI: 10.23902/trkjnat.558252

Received: 26 April 2019, Accepted: 23 July 2019, Online First: 5 August 2019, Published: 15 October 2019

\begin{abstract}
In this study, morphological and anatomical features of two morphologically similar species (Iris peshmeniana Güner \& T. Hall. and Iris aucheri (Baker) Sealy) within the Scorpiris Spach subgenus (Juno iris) of the genus Iris L. were determined and similarities and differences between the two species were discussed. Iris peshmeniana is endemic to Turkey and its spreading area is protected because of exctinction threat. Iris aucheri is not endemic to Turkey and it has a limited distribution in the country. The cross-sections from root, scape and leaves and surface-sections from leaves of species were taken. Anatomical and morphological evaluations of the collected and obtained samples revealed differences in plant size, leaf number, width and length, periant tube length, fall length, standard structure, capsule length and width, bract and bracteole structure, length of style branches and testa structure of seeds and in the number of exoderma and cortex layers, margin structure of cortex paranchyma cells, structure of the root center cylinder, xylem strand number, status micropapillae in lower epiderma, layer number of palisade and spongy parenchyma and status of sclerenchyma cap. Although there were some differences in morphological and anatomical features, based on similar anatomical and morphological features revealed in the present study, it has been suggested that I. peshmeniana may be a subspecies of I. aucheri.
\end{abstract}

Key words: Scorpiris taxa, morphology, anatomy.

Özet: Bu çalışmada, Iris L. cinsinin Scorpiris Spach altcinsinde (Juno iris) morfolojik olarak benzer iki türün (Iris peshmeniana Güner \& T. Hall. ve Iris aucheri (Baker) Sealy) morfolojik ve anatomik özellikleri belirlendi ve iki tür arasındaki benzerlikler ve farklılıklar tartışıldı. Iris peshmeniana Türkiye'ye endemiktir ve tükenme tehlikesi altında olduğundan onun yayılış alanı koruma altındadır. Iris aucheri Türkiye'ye endemik değildir ve ülkede sınırlı bir yayılışa sahiptir. Türlerin kök, skap ve yapraklarından enine kesitler, yapraklardan yüzeysel kesitler alındı. Toplanan ve elde edilen örneklerin anatomik ve morfolojik değerlendirmeleri, bitki boyu, yaprak sayısı, eni ve boyu, periant tüp boyu, dış tepal boyu, iç tepal yapısı, kapsül boyu ve eni, brakte ve brakteol boyu, stilus parçalarının boyu ve tohumların testa yapısı ve eksoderma ve korteks tabakalarının sayısı, korteks parankima hücrelerinin kenar yapısı, kök merkezi silindirin yapısı, ksilem kol sayısı, alt epidermadaki mikropapillaların durumu, palizat ve sünger parankimanın tabaka sayısı ve sklerenkima kümesinin durumundaki farklılıklarla ortaya çıkarıldı. Morfolojik ve anatomik özelliklerdeki bazı farklılıklara rağmen, bu çalışmada ortaya konan benzer morfolojik ve anatomik özelliklere dayanarak I. peshmeniana'nın I. aucheri'nin alttürü olabileceği öne sürülmüştür.

\section{Introduction}

The genus Iris L. is a different and crowded group of Iridaceae family in Turkey (Mathew 1984). Some species of the genus are used as ornamental plant because of their showy and fragrant flowers and some species which have various secondary metabolities in some organs, especially in rhizomes and bulbs, are used to treat many diseases (Baytop 1999, Fang et al. 2008, Sabrin et al. 2012, Kukula-Koch et al. 2015). Therefore, representatives of the genus are among significant geophytes both inTurkey and over the world.

The two taxa, I. peshmeniana Güner \& T. Hall and $I$. aucheri (Baker) Sealy studied in the present study are placed in the subgenus Scorpiris Spach (Juno irises) of the genus. Scorpiris is represented in Turkey with 10 naturally growing taxa of which 5 are endemic to the country (Güner 2012). The subgenus is a different subgenus among other subgenera of Iris with its rootstock, bulbs, fleshy persistent roots, floral morphology, falcate leaves, bifacial leaf anatomy, reduced standards, well developed falls, polen morphology, and arils on the seeds (Rudall \& Mathew 1993, Mathew 2001, Kandemir \& Yakupoğlu 2016). The distributions of most Scorpiris members in Turkey are rather limited due to various reasons (ecological factors, fires, road and dam construction, human pressures, grazing, expansion of agriculture areas). For instance, I. aucheri is distributed only in the vicinity of Gaziantep and Diyarbakır. It is an endangered species because of dense dam and road constructions in this region and therefore needs an urgent protection. Iris peshmeniana, on the other hand, is distributed only around Malatya-Şakşak Mountains. Although $I$. peshmeniana is morphologically very similar to I. aucheri, 
former differs from the latter with its creamy yellow flowers and less leaves. Iris aucheri has whitish to dark blue flowers and many leaves. Iris peshmeniana was first collected from Kubbe Passage of Şakşak Mountains and published as a new species in List of Turkey Plants (Vascular Plants) in 2012 (Güner 2012). Although there are irregular grazing and road widening activites in distributional area of I. peshmeniana, it has very strong growth potential. Even so, its distribution area is protected for future destruction. Since it has showy and nice flowers, it can potentially be used as an ornamental plant in future. As Iris aucheri has large bulbs and powerful plant structure, high young bulb growing ability, grows and reproduces fast in dry and wet areas and has beautiful colourful flowers and to be used in winter and in rock gardens and balconies (Usta 2002, Güner 2012).

The purpose of this study is to determine the similar and different morphological and anatomical features of the two species and to solve problems about them.

\section{Materials and Methods}

Iris aucheri was collected in April 2014 from natural populations in Şanliurfa (Karaca Mountain) and Gaziantep (Sof Mountain) provinces at an altitude of 1100-1200 m. asl. Iris peshmeniana was obtained from Nezahat Gökyiğit Botanical Garden and was collected from Malatya-Pötürge, Kubbe Passage of Şakşak Mountains at $1855 \mathrm{~m}$. asl. The localities where the specimens were collected are shown in Fig. 1.

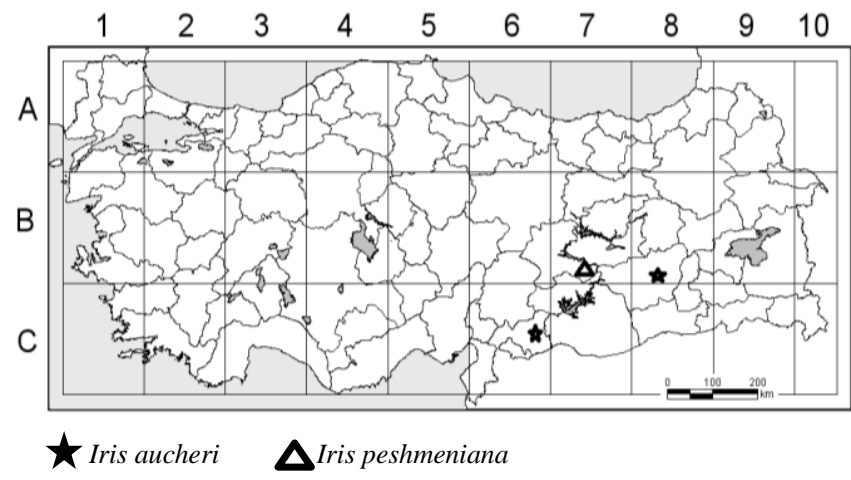

Fig. 1. Map of the region where the plant samples are collected

Taxonomic description of the taxa were made according to Mathew (1984) and Güner (2012). Fresh plant samples were fixed in $70 \%$ ethyl alcohol solution and anatomical investigations were carried out using these samples. The cross sections of root, scape and leaves and surface section of leaves were taken and photographed by research microscope (Leica ICC50 HD). The sartur reagent was used for the cross and surface-sections of above and below-ground parts (Çelebioğlu \& Baytop 1949). Anatomical and morphological measurements were made with a micrometric ocular and a ruler, respectively. The features considered for anatomical measurements are given in Table 1. Mean epidermal and stoma cells numbers per 1 $\mathrm{mm}^{2}$ of surface section were determined (Table 2). Cell counts were obtained by using a research microscope. The stomata index was calculated according to the descriptions of Mesdner \& Mansfield (1968).
Table 1. Anatomical features of studied Iris species (all dimensions are in $\mu \mathrm{m})$.

\begin{tabular}{|c|c|c|}
\hline Anatomical features & I. aucheri & I. peshmeniana \\
\hline \multicolumn{3}{|c|}{ Root } \\
\hline Width of epidermal cells & $20-22$ & $18-22$ \\
\hline $\begin{array}{l}\text { Layer number of } \\
\text { exodermis }\end{array}$ & $3-5$ & $2-4$ \\
\hline Layer number of cortex & $18-22$ & $13-15$ \\
\hline Diameter of cortex cells & $60-85$ & $65-85$ \\
\hline $\begin{array}{l}\text { Margin structure of } \\
\text { cortex parenchyma cells }\end{array}$ & $\begin{array}{l}\text { apparent } \\
\text { undulated }\end{array}$ & light undulated \\
\hline Diameter of endoderma & $20-25$ & $22-26$ \\
\hline $\begin{array}{l}\text { Tracheae number of pith } \\
\text { region }\end{array}$ & 1 & 3 \\
\hline Xylem strand number & $8-10$ & $9-11$ \\
\hline Trachea diameter & $50-60$ & $50-70$ \\
\hline Dark contents & present & present \\
\hline \multicolumn{3}{|c|}{ Scape } \\
\hline $\begin{array}{l}\text { Diameter of epidermal } \\
\text { cells }\end{array}$ & $20-22$ & $22-26$ \\
\hline $\begin{array}{l}\text { Status of vascular } \\
\text { bundles }\end{array}$ & scattered & scattered \\
\hline \multicolumn{3}{|c|}{ Leaf } \\
\hline $\begin{array}{l}\text { Diameter of upper } \\
\text { epidermal cells }\end{array}$ & $54-56$ & $48-53$ \\
\hline $\begin{array}{l}\text { Side wall structure of } \\
\text { upper and lower } \\
\text { epidermal cells }\end{array}$ & straight & straight \\
\hline Cuticle thickness & $9-13$ & $10-15$ \\
\hline $\begin{array}{l}\text { Length of parenchyma } \\
\text { cells }\end{array}$ & $30-37$ & $27-31$ \\
\hline $\begin{array}{l}\text { Width of parenchyma } \\
\text { cells }\end{array}$ & $25-31$ & $23-26$ \\
\hline Tracheae diameter & $16-18$ & $14-15$ \\
\hline $\begin{array}{l}\text { Diameter of lower } \\
\text { epidermal cells }\end{array}$ & $30-36$ & $30-34$ \\
\hline Micropapillae & light & dense \\
\hline Keels & not apparent & $\begin{array}{l}\text { extremely } \\
\text { apparent }\end{array}$ \\
\hline $\begin{array}{l}\text { Structure and layer } \\
\text { number of mesophyll }\end{array}$ & bifacial, 7-8 & bifacial, 7 \\
\hline
\end{tabular}

Table 2. Stomata measurements and stomata index for the studied Iris species. The lower surfaces of the leaves were considered for both species.

\begin{tabular}{|c|c|c|c|c|c|}
\hline & 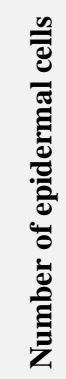 & 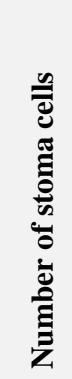 & 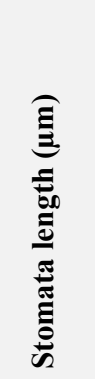 & 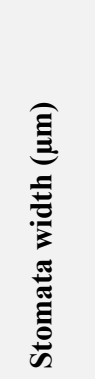 & 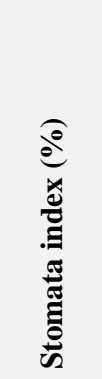 \\
\hline I. aucheri & 102 & 138 & 36-40 & $30-32$ & $57.5 \%$ \\
\hline I. peshmeniana & 108 & 133 & $38-42$ & $33-35$ & $55.2 \%$ \\
\hline
\end{tabular}




\section{Results}

The results of anatomical and morphological measurements and the obtained measurement and index data related to stomata are given in Tables 1-3.

\section{Morphological features}

\section{Iris aucheri}

Plant 15-40 cm in length; bulb $2.5-3.5 \mathrm{~cm}$ in diameter, covered with papery tunics; storage roots fleshy; stem concealed by leaves at anthesis; leaves 5-12 well developed at anthesis, $25 \times 2.4-4.3 \mathrm{~cm}$, lanceolate, usually falcate, canaliculate, glabrous or minutely papillose, glossy green above, upper shorter and bractlike and pale at base (Fig. 2A); bract and bracteole longacuminate, $5.1-6.3 \times 1.6-2.4 \mathrm{~cm}$ and 5.8-6.3 $\times 1.5-2.5$ $\mathrm{cm}$, respectively; perianth tube $5-6.6 \mathrm{~cm}$ in length; flowers 3-6 deep blue to nearly white; falls $4-5.5 \mathrm{~cm}$ in length; claw winged, 2.5-3.5 $\times$ 2-2.4 cm, lamina orbicular or eliptic, with band of yellow hair along side of middle line, $1.5-2 \times 1.4-2.3 \mathrm{~cm}$ undulate; crest prominent, erose-crenulate, yellow or cream, 2.3-2.5 $\mathrm{mm}$; standards patent to deflexed, obovate, 2.1-3.4 $\times$ $0.5-1.3 \mathrm{~cm}$; filament $1.2-1.6 \mathrm{~cm}$ in length; anther 1.0-1.2 $\mathrm{cm}$ in length; style branches $3.5-5 \mathrm{~cm}$ in length, pale blue; ovary narrow, 10-12 × 2-4 mm; capsule narrowly cylindrical, 6-7 × 1.2-1.4 cm, without beak; seeds $3 \mathrm{~mm}$, rugose, dark brown.

\section{Iris peshmeniana}

Plant 9-16 cm in length; bulb 2.2-3.6 cm in diameter, long ovoid, tunic papery and dark brown; storage roots fleshy; stem hidden by leaves, unbranched, with 1-4 flowers (Fig. 2B); leaves 5-8, strongly falcate, canaliculate, linear lanceolate, lowermost leaves 7.5-15 $\times 1.7-3.7 \mathrm{~cm}$, slightly undulate, regulary veined, pale green, glossy green above, margins white and smooth; bract and bracteoles equal, lower straw coloured and rounded, upper green and carinate; bracts 5.3-6.1 × 1.8$2.6 \mathrm{~cm}$, lanceolate scabridulous at margin and very narrow transparent stripe; bracteole 5.7-6.5 × 1.7-2.3 $\mathrm{cm}$, lanceolate, acuminate in flower; perianth tube 1.8-4 $\mathrm{cm}$ in length; flowers yellow with a yellow central patch and crest on falls; falls 4.3-4.6 $\times 2.3-2.8 \mathrm{~cm}$, panduriform, creamy yellow with a large yellow patch; claw 2.7-3 $\times 2.3$-2.8, winged with a $3 \mathrm{~mm}$ wide band of yellow hair; blade $1.5 \times 1.8-2.2 \mathrm{~cm}$, oblong, narrower than claw; crest $2.4 \mathrm{~mm}$, crinkly and yellow; standards reflexed, $2.3-3.1 \times 1.1-1.5 \mathrm{~cm}$, spathulate to obovate, creamy yellow, rarely with a yellow line; filaments 1.5 $1.8 \mathrm{~cm}$ in length; anthers $1.2-1.3 \mathrm{~cm}$ in length; style branches $4.1-4.5 \times 1-1.6 \mathrm{~cm}$, creamy yellow with a central yellow line; crests vertical to ascending, outer margins irregularly crenate; stigma bilobed, $0.3 \times 0.6$ $\mathrm{cm}$; ovary 10-13 $\times 3-4 \mathrm{~mm}$; capsule oblong triangular with rounded margins, 2.5-3.5 $\times 0.8 \mathrm{~cm}$ without beak, 30-42 with seed; seeds pear shaped, acute, dark brown, $0.3 \times 0.2 \mathrm{~cm}$, slightly rugose.

\section{The root anatomical features}

\section{Iris aucheri}

Epiderma is made of a single layer of small and rectangular shaped cells. Exoderma is 3-5 layered and large celled. Cortex parenchyma is multilayered (18-22 layered). Parenchyma cells are large, oval shaped and have dense dark contents. Margins of parenchyma cells are apparently undulated. Endoderma and pericycle are single layered and parenchymatic. The thickness in endodermal cells are three sided and oriented to pericycle. There is no thickness towards cortex. Xylem has 8-10 strands and phloem elements are obvious. In the pith region, there is one large trachea (Fig. 3A).

\section{Iris peshmeniana}

Epiderma is made of a single layer of large and rectangular shaped cells. Exoderma is 2-4 layered. Cortex is multilayered (13-15 layered) and parenchymatic. Parenchyma cells are large and oval or hexagonal shaped and have dense dark contents. Margins of parenchyma cells are lightly undulated. Endoderma is single layered and parenchymatic. The thickness in endoderma are three sided and oriented to pericycle. Pericycle is single layered, oval shaped and parenchymatic. Phloem is obvious, xylem has 9-11strands. There are metaxylem elements in the center of the root (Fig. 3B). The pith area is absent in the root. There are three large trachea in the pith.

\section{The scape anatomical features}

\section{Iris aucheri}

The cuticle is thick in the cross-section of scape. Epiderma is made of a single layer of small and square shaped cells. Papillae and micropapillae are seen on epiderma and cuticle, respectively. Cortex is composed of oval or circular shaped and large parenchyma cells (Fig. 4A). There are dense druses and rafita crystals and rare dark contents in the cortex parenchyma cells (Fig. 5A). Large and small vascular bundles are scattered. Xylem elements are in half-moon form. The vascular bundles in the pith are large, vascular bundles in the outer layers are small. The pith parenchyma cells are larger than the cortex parenchyma cells.

\section{Iris peshmeniana}

In the outer surface of the scape, there is a thick cuticle. Epiderma is made of a single layer of square shaped cells and with papillae. Cortex contains oval or circular shaped and large parenchyma cells. The sclerenchymatic cylinder in the cortex is not present. Vascular bundles are scattered in the cortex and central cylinder (Fig. 4B). The xylem and phloem elements are apparent in the vascular bundles. Xylem elements are in half-moon form. Bundle sheath is not obvious around vascular bundles. In the cortex parenchyma, there are rare dark contents, dense rafita and druses crystals (Fig. 5B). The pith consists of large, thin walled parenchyma cells 

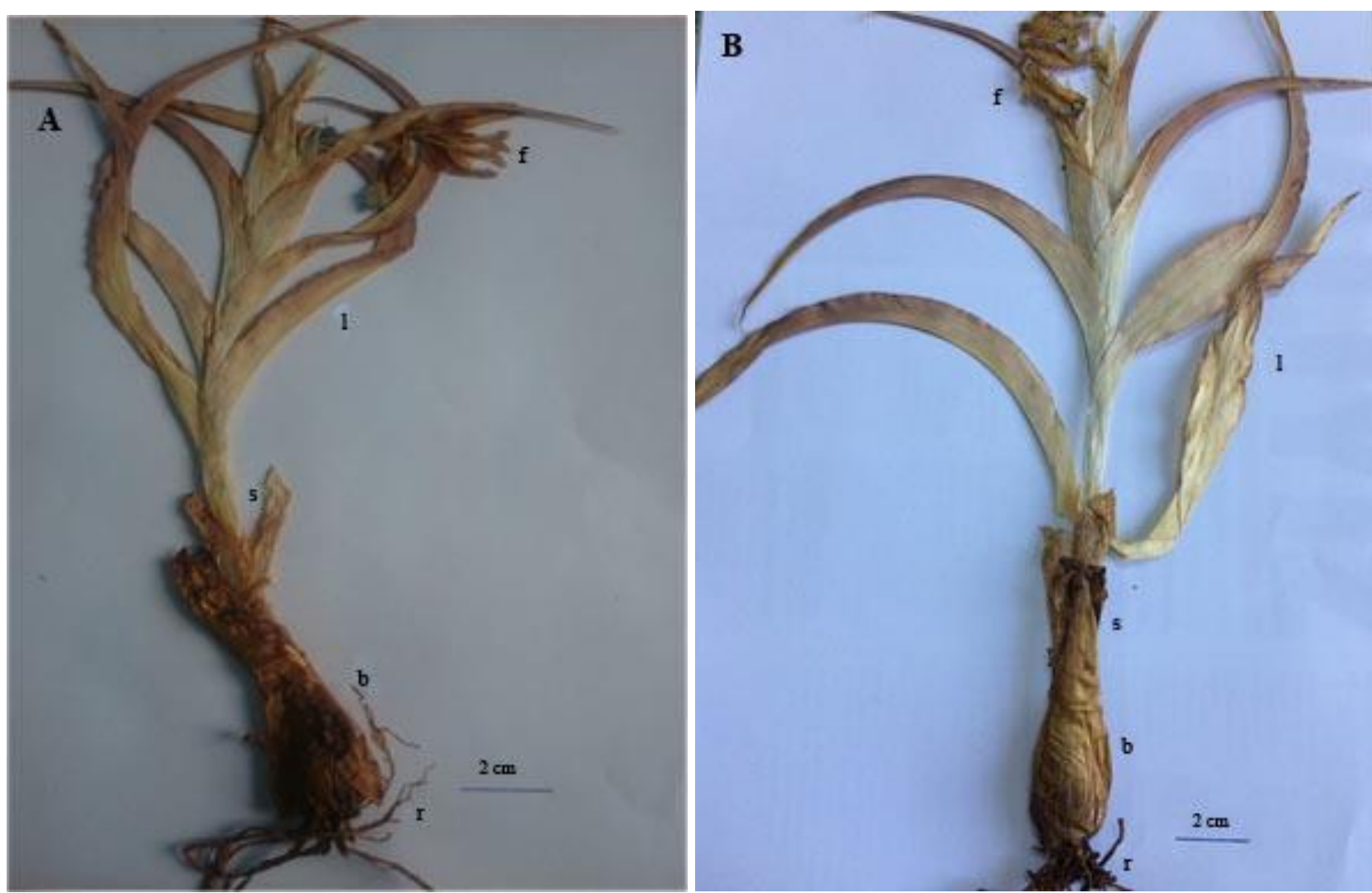

Fig. 2. General appearance of herbarium samples of Iris aucheri (A) and Iris peshmeniana (B). r: root, b: bulb, s: scape, l: leaf, f: flower.
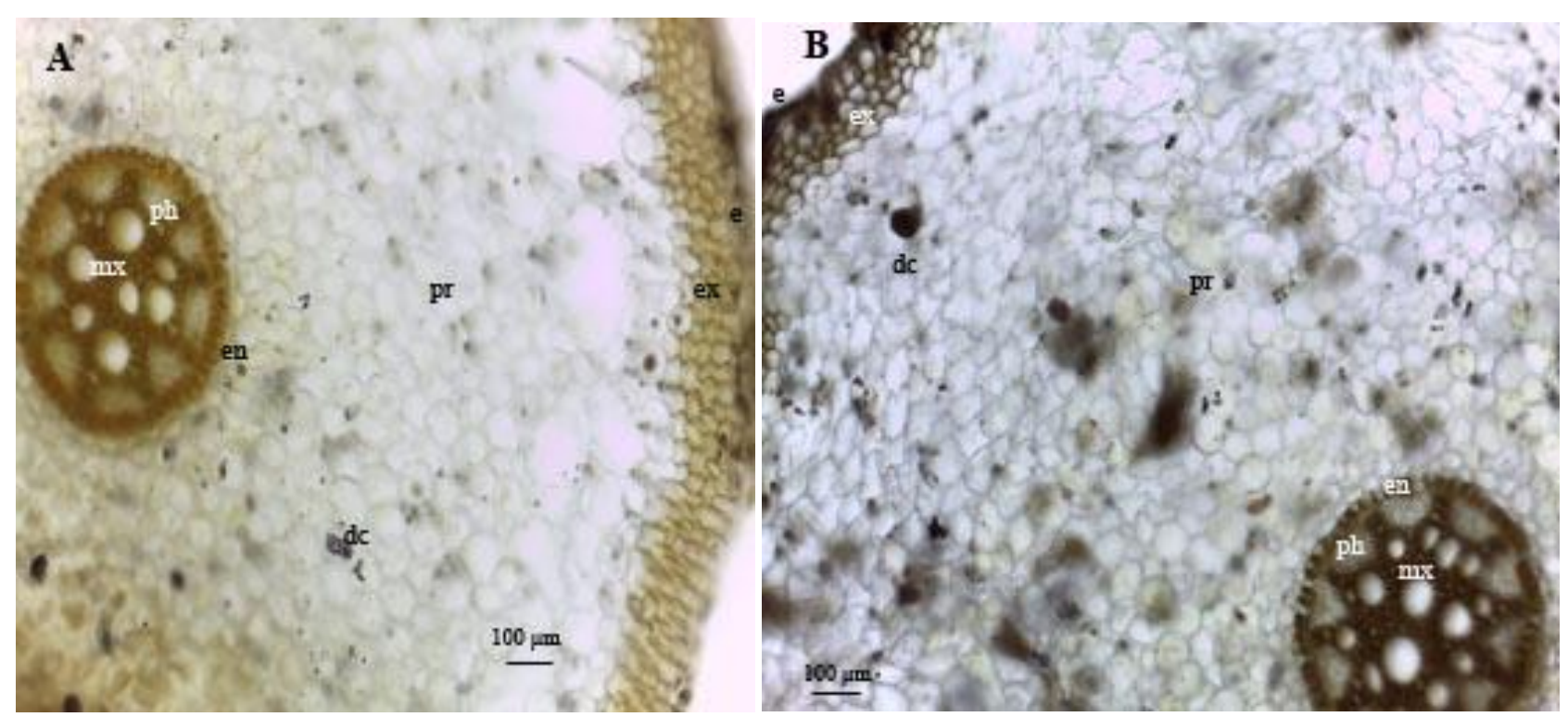

Fig. 3. Root cross sections of Iris aucheri (A) and Iris peshmeniana (B). e: epiderma, ex: exoderma, pr: parenchyma, en: endoderma, mx: metaxylem, ph: phloem, dc: dark content. 

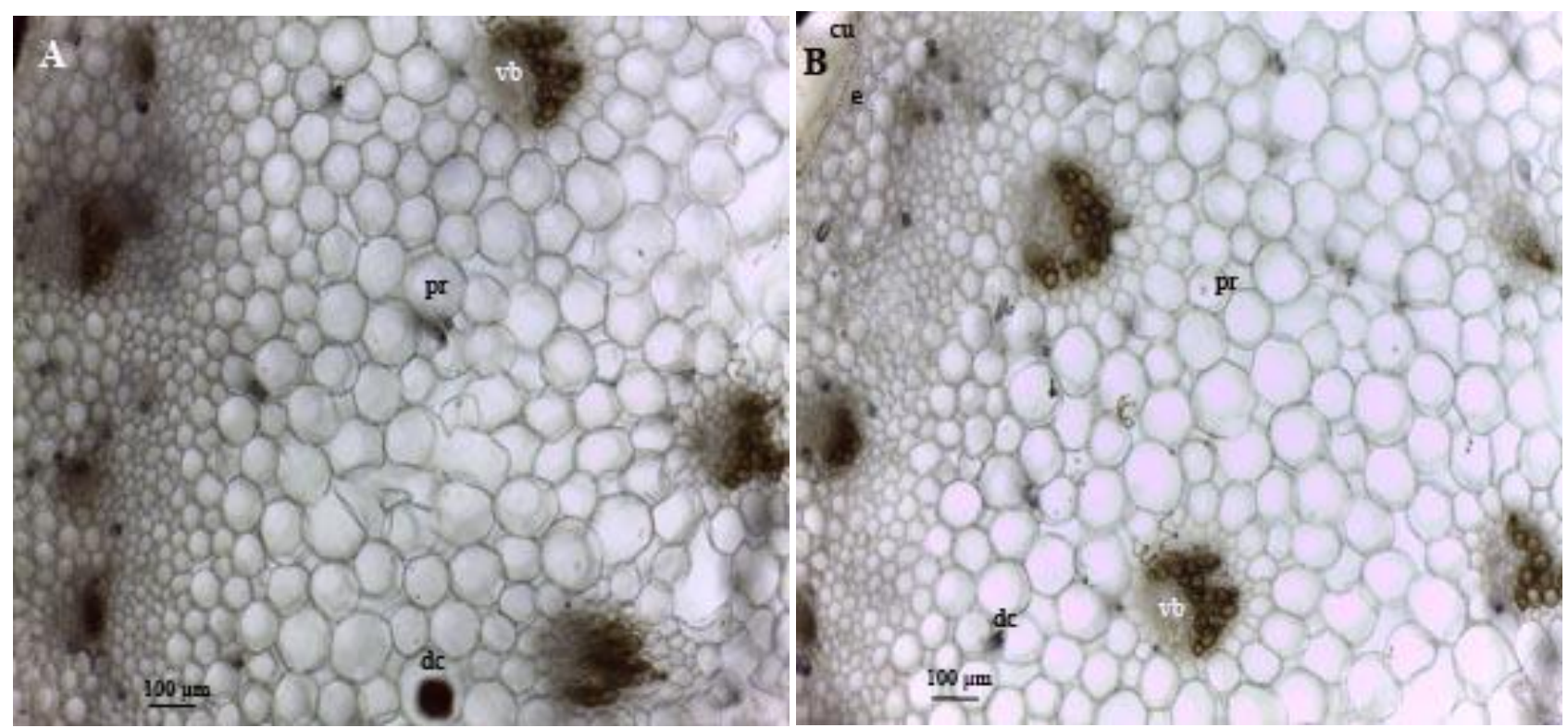

Fig. 4. Scape cross sections of Iris aucheri (A) and Iris peshmeniana (B). cu: cuticle, e: epiderma, pr: parenchyma, vb: vascular bundle, dc: dark content.
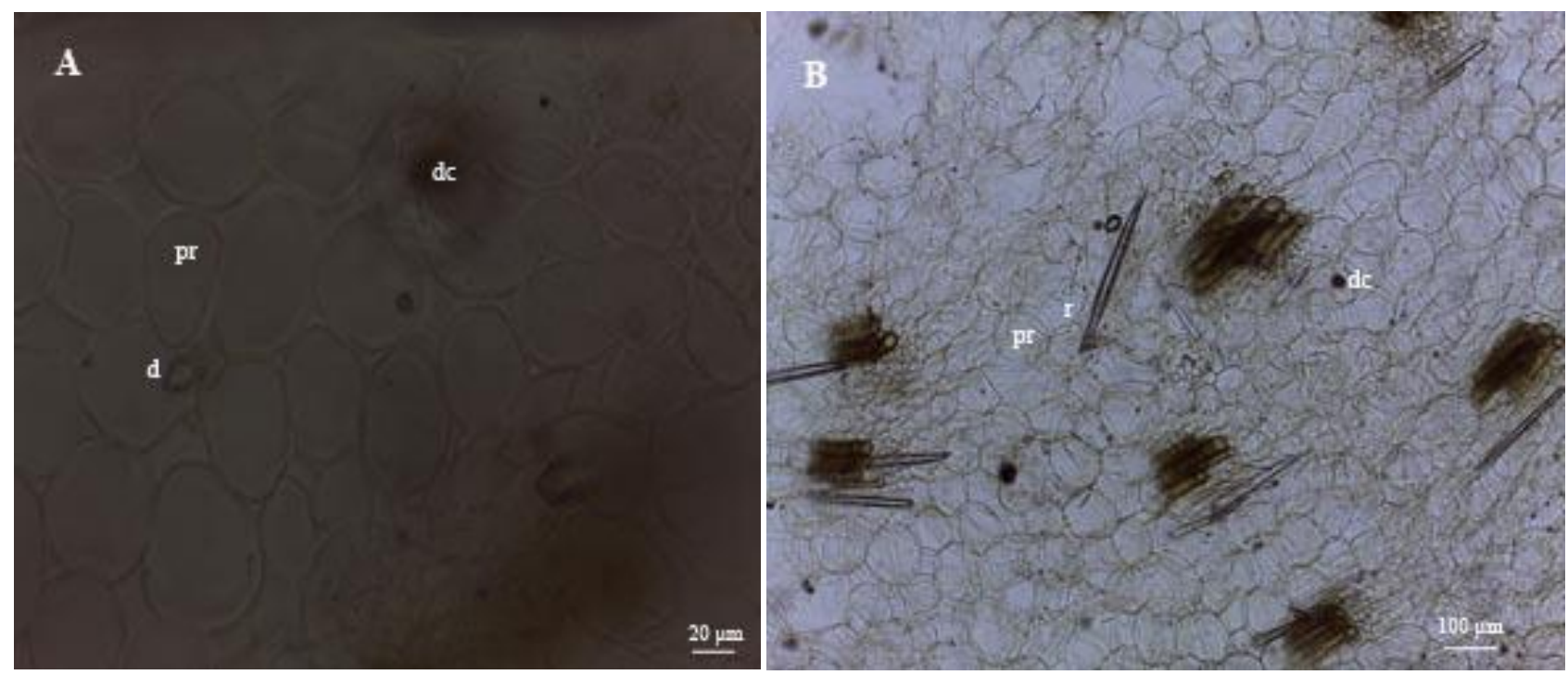

Fig. 5. Crystals in scape cross sections of Iris aucheri (A) and Iris peshmeniana (B). pr: parenchyma, d: druse crystals, r. rafita crystals, dc: dark content.

\section{The leaf anatomical features}

\section{Iris aucheri}

Leaf is in bifacial type (Fig. 6A). Upper epidermal cells are rectangular shaped, very large, single layered and have papillae. Cuticle layer is thick and it has micropapillae. Lower epidermal cells are rectangular shaped, small and have papillae. The upper epidema without stomata. Stomata are dense and large in lower epiderma (Fig. 7A). In the upper epiderma, there are dense crystal granules, rare hexagonal crystals and bulliform cells (Fig. 8A). Mesophyll is 7-8 layered with rare styloids. The palisade-like parenchyma is 3-5 layered in the upper epiderma. These cells are large and with dense chloroplast. The spongy-like parenchyma is 2-3 layered, oval shaped and with less chloroplast. Rare styloids are observed in the mesophyll cells. Vascular bundles are typically in a single row. Sclerenchyma cap is rarely seen at the phloem poles of vascular bundles, leaf margin and the keels in the lower epiderma. Keels are light round shaped and are not apparent. There are subadjacent marginal epiderma in large vascular bundles. At xylem pole of vascular bundles, sclerenchyma cap is not seen. There are oval shaped, large parenchyma cells lacking chloroplast at the xylem pole of vascular bundles.

\section{Iris peshmeniana}

Leaf is in bifacial type. Upper and lower epiderma are single layered, upper epiderma is with large square shaped cell and lower epiderma is small rectangular shaped cells. Papillae are seen on the upper and lower epiderma. Cuticle with micropapillae is thick. Dense micropapillae 
present in lower epiderma (Fig. 6B). Stomata are not seen in the upper epidema. Stomata are large and frequent in the lower epiderma (Fig. 7B). There are more dense crystal granules, rare hexagonal crystals and bulliform cells in upper epiderma (Fig. 8B). Crystal granules in lower epiderma are rare. Bifacial mesophyll is 7 layered, the palisade-like parenchyma cells with dense chloroplast are 1-3 layered. The spongy-like parenchyma cells, which are large, oval shaped and with rare chloroplast, are 3-4 layered. There are rare styloids in the mesophyll.

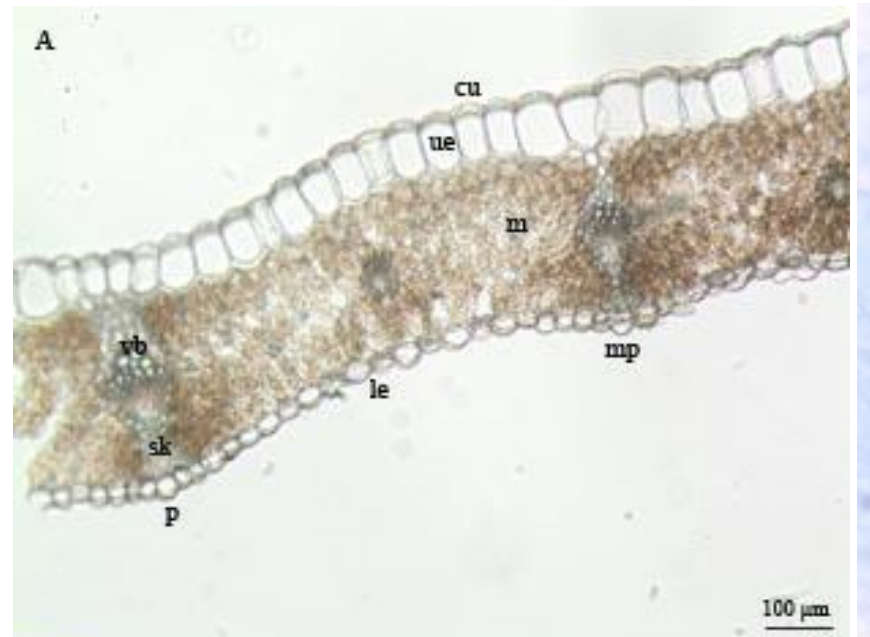

Sclerenchyma cap is found at the xylem pole of vascular bundles, leaf margin and the keels in lower epiderma. Keels are round shaped and extremely apparent. Mesophyll cells present between sclerenchyma cap and phloem of vascular bundles. Sclerenchma cap is almost adjacent to lower epiderma. In the mesophyll cells, rare styloids are found. At phloem pole of vascular bundles, sclerenchyma cap is not obtained. The subadjacent marginal epiderma is in large vascular bundles.

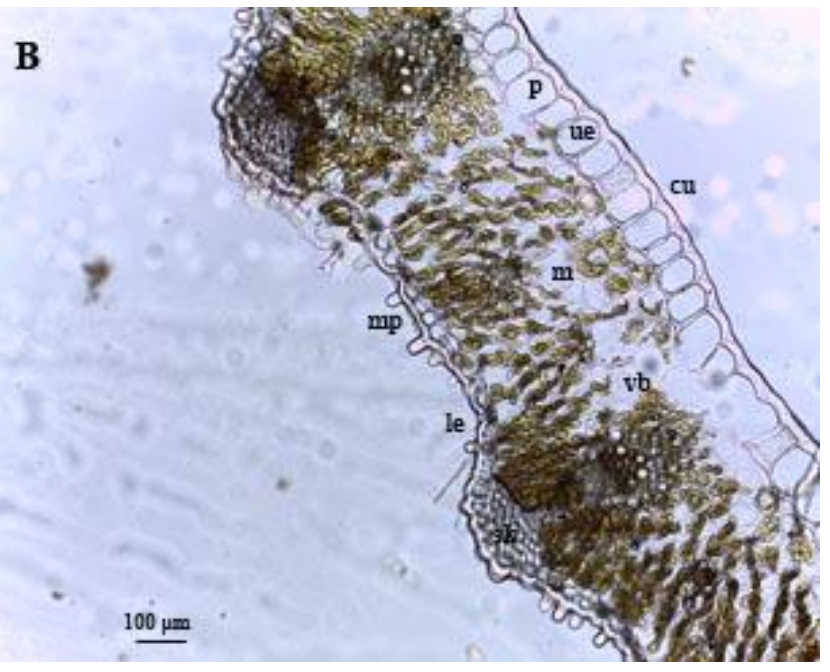

Fig. 6. Cross sections of leaves of Iris aucheri (A) and Iris peshmeniana (B). cu: cuticle, ue: upper epiderma, le: lower epiderma, m: mesophyll, vb: vascular bundle, p: papillae, mp: micropapillae, sk: sclerenchyma.
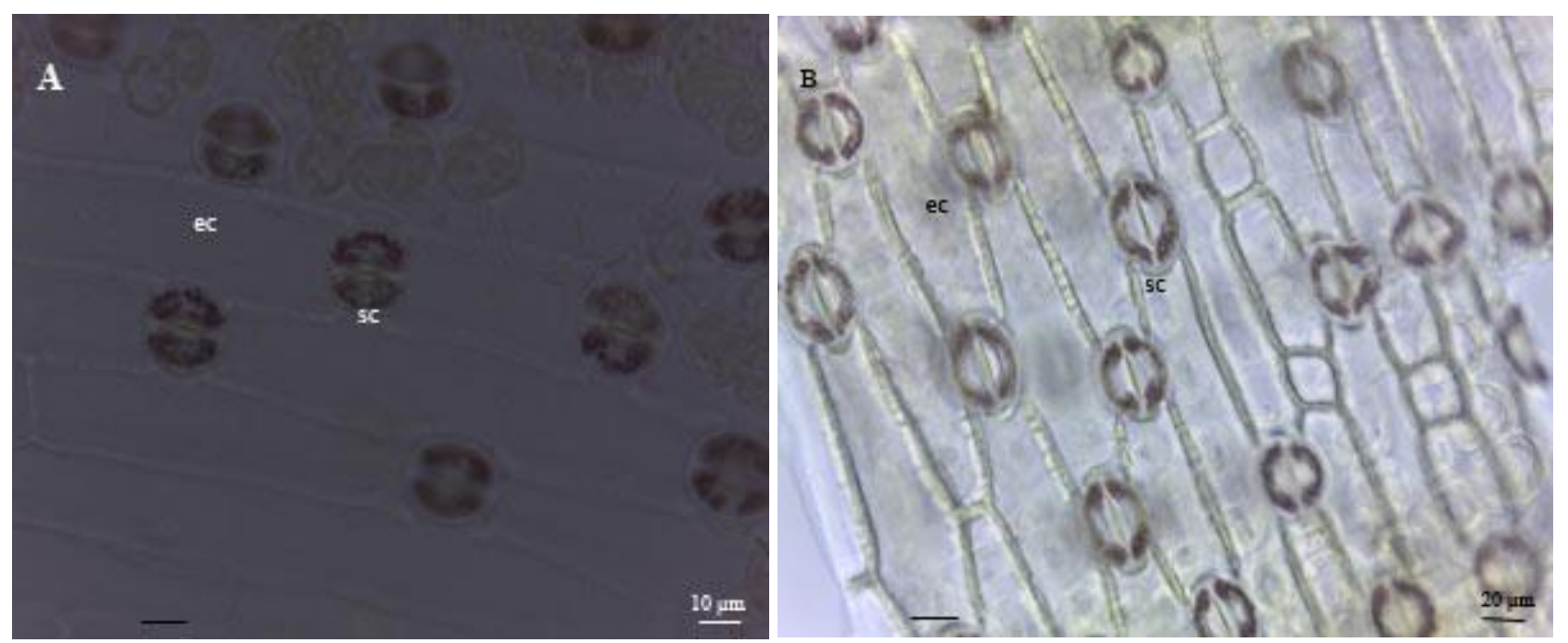

Fig. 7. Surface sections of leaves of Iris aucheri (A) and Iris peshmeniana (B). ec: epidermal cell, sc: stomata cell. 

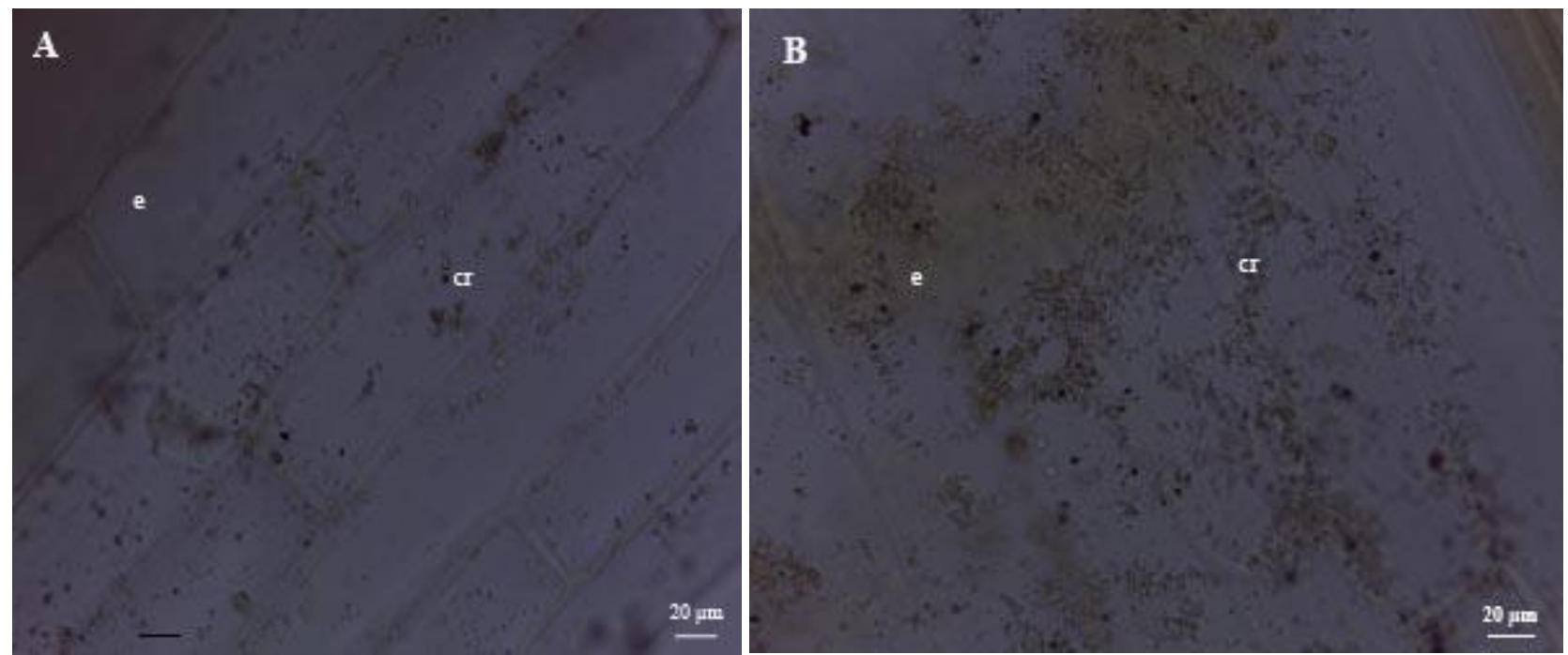

Fig. 8. Crystals in leaf cross sections of upper epiderma of Iris aucheri (A) and Iris peshmeniana (B). e: epiderma, cr: crystal granules.

\section{Discussion}

In this study, morphological and anatomical features of two endangered species of the subgenus Scorpiris in Turkey, Iris aucheri and I. peshmeniana were compared. The distinguishing anatomical features of taxonomic value were determined and given in Tables 1-2.Variations were seen in flower colours of the studied species and according to these variations, these taxa were reported as different species (Güner 2012). Variations were also found in some other flower features of other Scorpiris taxa in Turkey and the world (Mathew 2001, Guo 2015, Kandemir \& Yakupoğlu 2016). The evolutionary significance of these different features in flower characters is been known yet. Moreover, the pollination biology of Scorpiris is little known. Due to the above situations, taxonomic problems of taxa placed within Scorpiris are still waiting to be solved. The present results showed that differences were also present between the studied species in plant size, leaf number, width and length, periant tube, fall length, standard structure, capsule length and width, bract and bracteole structure, length of style branches and testa structure of seeds. These differences may be an outcome of the effects of the differing distributions of the species. On the other hand, if there are also intraspecific differences in morphological features of the samples collected in different localities, it reveales that ecological conditions affect morphological features of the plants.

The problems in taxonomy of Scorpiris group are caused by changes in flower colours, shape and size of perigon segments of this subgenus species (Boltenkov 2016). Scorpiris is also a very different group within the genus Iris with its members having fleshy storage roots, different bulbs, well developed falls, reduced standards, petaloid style branches, different testa structure and bifacial leaf anatomy (Rudall \& Mathew 1993, Mathew 2001, Dönmez \& Pinar 2001, Hall et al. 2001, Kandemir \&Yakupoğlu 2016). Despite these differences, this subgenus was not considered as separate genus by Tillie et al. (2000) who evaluated Scorpiris as a monophyletic group. On the contrary, Crespo et al. (2015) evaluated the Juno irises as a separate genus, according to recent taxonomic studies. On the other hand, there have been a lot of phylogenetic studies on Iris genus. However, data in phylogenetic studies are not enough to solve the relationships and problems in subgenera of the genus (Makarevitch et al. 2003, Wilson 2009, 2011, Guo \& Wilson 2013).

In the anatomical study, differences were obtained in the number of exoderma and cortex layers, margin structure of cortex paranchyma cells and the root center cylinder. In the roots of I. peshmeniana, xylem strands, number of exoderma and cortex layers, margin structure of cortex paranchyma cells were 9-11, 2-4, 13-15 and light undulated, respectively. Xylem strands, number of exsoderma and cortex layers, margin structure of cortex paranchyma cells were 8-10, 3-5, 18-22 and apparent undulated in the root of I. aucheri, respectively. In the root pith region of I. peshmeniana, there is three large trachea. However, in the root pith region of I. aucheri, one large trachea is seen. The above mentioned root anatomical features may be used as distinguishing characters between the two taxa. The similar situation was found in the roots of some other Iris taxa by researchers (Nicolic \& Mitic 1991, Mitic et al. 2000, Gontova \& Zatylnikova 2013, Kandemir \& Yakupoğlu 2016, Kandemir \& Çelik 2017). No significant distinguishing features were found in the scape of the studied species. Meaning that, the two species are very similar to each other in terms of scape anatomical features.

Although the leaves of the studied species have bifacial type from anatomical point of view, some differences and simililarities were seen between the two species. The upper and lower epidermal cells of I. aucheri are larger than I. peshmeniana. In I. aucheri, the upper and lower epidermal cells are rectangular or square and rectangular shaped, respectively. However, the upper and lower epidermal cells of I. peshmeniana are square and 
rectangular shaped, respectively. Micropapillae and papillae on cuticle and the upper epiderma of the two species are rare. In lower epiderma of I. peshmeniana, micropapillae are more conspicuous and denser than $I$. aucheri. Also, cuticle layer on both epiderma of I. aucheri is thinner than I. peshmeniana. The cuticles on both epiderma layers of I. peshmeniana are too thick. In the upper epiderma of I. aucheri and I. peshmeniana, dense crystal granules, rare hexagonal crystals and bulliform cells were found. However, dense crystal granules, hexagonal crystals and bulliform cells were not found in the lower epiderma of two species. Also, stomata were not seen in the upper epidermis, while stomata were seen dense and large in the lower epidermis of the two species. Stomata of I. peshmeniana are larger and rarer than $I$. aucheri. Mesophyll is 7-8 layered in I. aucheri and 7 layered in I. peshmeniana. The palisade and spongy-like parenchymatous cells are 3-5 and 2-3 layered in $I$. aucheri, respectively. But, the palisade and spongy-like parenchymatous cells are 3-4 and 2-4 layered in $I$. peshmeniana, respectively. In I. peshmeniana, sclerenchyma cap in the large vascular bundles is at the xylem poles of vascular bundles, leaf margin and the keels in the lower epidermis. Keels are round shaped and extremely apparent. There are mesophyll cells between sclerenchyma cap and phloem of vascular bundles. Sclerenchyma cap in large vascular bundles of I. aucheri

\section{References}

1. Baytop, T. 1999. Used Medicine Plants in Turkey, pp.137370. In: (Baytop, T.). Therapy with Plant In Turkey (Past and Present). Nobel Medicine Bookstores, İstanbul, 480 pp.

2. Boltenkov, E.V. 2016. Typification and nomenclatural notes on twenty-eight names of Juno irises (Iridaceae) from Central and South Asian. Phytotaxa, 260: 223-234.

3. Celep, A. 2011. An Anatomical Study On the Genus Iris L. Subgenus Scorpiris Spach. Species Growing in Turkey. Master Thesis. Selcuk University, Science Institute, Konya, $54 \mathrm{pp}$.

4. Crespo, M.B., Martínez-Azorín, M. \& Mavrodiev, E.V. 2015. Can a rainbow consist of a single colour? A new comprehensive generic arrangement of the 'Iris sensu latissimo' clade (Iridaceae), congruent with morphology and molecular data. Phytotaxa, 232: 1-78.

5. Çelebioğlu, S. \& Baytop, T. 1949. A New Reagent For Microscopical Investigation of Plant. Publication of the Institute of Pharmacognosy, İstanbul, $301 \mathrm{pp}$.

6. Dönmez, E.O. \& Pınar, N.M. 2001. The clypeate polen grains of Turkish Iris (Iridaceae): Subgenus Scorpiris Spach. Turkish Journal of Botany, 25: 57-62.

7. Fang, R., Houghton, P.J. \& Hylands, R.L. 2008. Cytotoxic effects of compounds from Iris tectorum on human cancer cell lines. Journal of Ethnopharmacology, 118: 257-263.

8. Gontova, T.N. \& Zatylnikova, O.A. 2013. Comparative morphological and anatomical study of leaves and stems of Iris pseudocorus and Iris sibirica. International Journal of Pharmacy and Pharmaceutical Ssiences, 5: 574-578. is rare at the phloem poles of vascular bundles, leaf margin and the keels in the lower epiderma. Rudall (1991) in Tigridieae species, Kandemir (2015) in Hermodactyloides species, Kandemir \& Çelik (2017) in three Iris species, Kandemir et al. (2019) in some Scorpiris species reported sclerenchyma cap at the phloem poles in leaf anatomy. Keels in lower epiderma are light round shaped and are not apparent and they are not quite frequent. The subadjacent marginal epidermis is seen in large vascular bundles of both taxa. The similar phenomenon was seen in leaf anatomy of Tigridieae and Scorpiris taxa (Rudall 1991, Celep 2011, Kandemir \&Yakupoğlu 2016, Kandemir et al. 2019). Rare styloids are obtained in the mesophyll cells of the studied species. The bifacial mesophyll structure is evidently conspicuous in leaf anatomy of I. aucheri.

Although there are different morphological and anatomical features with some taxonomic value between the two species, they are very close to each other. Although no consensus has been made about the taxonomic status of I. aucheri and I. peshmeniana, we suggest that I. peshmeniana and I. aucheri are dependent species on the base of the morphological and anatomical features. In other words, I. peshmeniana should be a subspecies of I. aucheri.

9. Guo, J. \& Wilson, C.A. 2013. Molecular phylogenetic study of the crested Iris based on five plastid markers. Systematic Botany, 38: 987-995.

10. Guo, J. 2015. Mechanisms for the evolution of complex and diversely elaborated sepals in Iris identified by comparative analysis of developmental sequences. American Jornal of Botany, 102: 819-832.

11. Güner, A. 2012. Iris L., pp. 535-540. In: Aslan, S., Ekim, T., Vural, M \& Babaç M.T. List of Turkey Plants (Vascular Pants), Publication of Nezahat Gökyiğit Botanic Garden and Floristic Research Society, Istanbul, $1290 \mathrm{pp}$.

12. Hall, T., Tillie, N. \& Chase, M.W. 2001. A re-evalution of the bulbous Irises. Annual of Botany, n.s. 58: 123-126.

13. Kandemir, N. 2015. Leaf anatomical properties of some rare and endemic Iris L. taxa and their reletions: Subgenus Hermodactyloides in Turkey. The Iranian Journal of Botany, 21: 142-151.

14. Kandemir, N. \& Yakupoğlu, H. 2016. Morphological and anatomical properties of endemic Iris nezahatiae distributed in the North-East Anatolia region (Turkey). Bitlis Eren University Journal of Science, 5: 104-112.

15. Kandemir, N. \& Çelik, A. 2017. Comparison of morphological and anatomical properties of endangered endemic Iris pamphylica and I. masia in Turkey. Acta Botanica Hungarica, 59: 371-388.

16. Kandemir, N., Çelik, A., Ullah F., Shah, S.N. \& Zaman, W. 2019. Foliar epidermal anatomical characteristics of taxa of Iris subg. Scorpiris Spach (Iridaceae) from Turkey. Microscopy Research \& Technique, 82: 764-774. 
17. Kukula-Koch, W., Sieniawska, E., Widelski, J., Urjin, O., Głowniak, P. \& Skalicka-Woźniak, K. 2015. Major secondary metabolites of Iris spp. Phytochemical Review, 14: $51-80$

18. Makarevitch, I., Golvonina, K., Scherbik, S. \& Blinov, A. 2003. Phylogenetic relationships of the Siberian Iris species inferred from noncoding chloroplast DNA sequences. International Journal of Plant Science, 164: 229-237.

19. Mathew, B. 1984. Iris L., 382-410. In: Davis, P.H. (eds). Flora of Turkey and the East Aegean Islands. Vol. 8. Edinburg University, Edinburg, 632 pp.

20. Mathew, B. 2001. Some aspects of the Juno group of irises. Annual of Botany, Special Volume: 113-122.

21. Mesdner, H. \& Mansfield, T.A. 1968. Physiolgy of stomata. McGraw-Hill., London, 144 pp.

22. Mitic, B., Nicolic, T. \& Liber, Z. 2000. Morphological and anatomical relationships in Alpine-Dinaric populations of the genus Iris L. Pallidae series (A. Kern.) Trinajstic (Iridaceae). Acta Societatis Botanicorum. Poloniae, 69: 285-291.

23. Nicolic, T. \& Mitic, B. 1991. Phenotic relationships within populations of Iris illyrica, Iris palliida and Iris pseudopallida (Iridaceae) with regard to morphological characteristics of epidermis. Acta Botanica Croatica, 50: 99-106.

24. Rudall, P. 1991. Leaf anatomy in Tigridieae (Iridaceae). Plant Systematic Evolution, 175: 1-10.

25. Rudall, P. \& Mathew, B. 1993. Leaf anatomy of the bulbous Irises. Botanische Jahrbücher, 115: 63-76.

26. Sabrin, I., Gamal, M. \& Nawal, M. 2012. New constituents from the rhizomes of Egyptian Iris germanica L. Molecules, 17: 2587-2598.

27. Tillie, N., Chase, M.W. \& Hall, T. 2000. Molecular studies in the genus Iris L.: a preliminary study. Irises and Iridaceae. Annals of Botany, 58: 105-112.

28. Usta, E. 2002. Classification of Turkish Iris L. (Iridaceae) By Phenetic Methods. Doctoral Thesis. Middle East Technical University, Science Institute, Ankara, 144 pp.

29. Wilson, C.A. 2009. Phylogenetic relationships among the recognized series in Iris section Limniris. Systematic Botany, 34: 277-284.

30. Wilson, C.A. 2011. Subgeneric classification in Iris reexamined using chloroplast sequence data.Taxon, 60: 27 35. 